\title{
Teacher Perceptions of Strategies for Improving ESOL Students' Academic English Skills: A K-12 Perspective
}

\author{
Jinyan Huang (Niagara University) \\ Alexis Smith (Niagara University) \\ R. Michael Smith (Niagara University)
}

\begin{abstract}
This study investigates five North American K-12 classroom teachers' perceptions of ESOL students' challenges in academic English skills and strategies for improving ESOL students' academic English skills. Seven distinct areas of interest emerged from the five interviews: 1) ranking of importance of academic listening, speaking, reading, and writing skills; 2) challenges that ESOL students face in the classroom; 3) strategies to help ESOL students in academic listening; 4) strategies to help ESOL students in academic speaking; 5) strategies to help ESOL students in academic reading; 6) strategies to help ESOL students in academic writing; and 7) strategies to assist ESOL students in overcoming challenges in academic English skills. This paper focuses on the implementation of coping strategies for K-12 ESOL students in academic English skills, as perceived by their classroom teachers.
\end{abstract}

\begin{abstract}
Résumé
Cette étude enquête sur les perceptions de cinq enseignants nord-américains de classes préscolaires à la 12e, des défis de leurs élèves ESOL face aux compétences en Anglais académique et des stratégies pouvant améliorer les compétences en Anglais académique de ces élèves ESOL. Sept domaines d'intérêt distincts ont émergés de ces cinq entretiens:1) degré d'importance académique des compétences en écoute, parler, lecture et écriture; 2) défis auxquels font face les élèves ESOL dans leurs salles de classe; 3) stratégies visant à aider les élèves ESOL avec leur écoute académique; 4) stratégies visant à aider les élèves ESOL avec leur parler académique; 5) stratégies visant à aider les élèves ESOL avec leur lecture académique; 6) stratégies visant à aider les élèves ESOL avec leur écriture académique; et 7) stratégies visant à assister les élèves ESOL à surmonter les défis liés aux compétences en Anglais académique. Cet article porte l'accent sur l'implémentation de stratégies d'adaptation pour les élèves de la maternelle à la $12^{\mathrm{e}}$ concernant les compétences en Anglais académique, telle que perçue par leurs enseignants
\end{abstract}

\section{INTRODUCTION}

The number of English-for-speakers-of-other-languages (ESOL) students has more than doubled since the 1980s and has recently grown significantly at North American schools (CBIE, 2002; U.S. Department of Education, 2008). Current research surrounding the proficient acquisition of English for Academic Purposes (EAP) has identified academic speaking, listening, writing and reading skills as challenging and/or potentially problematic areas for ESOL students studying in North American schools (Avalos, Plasencia, Chavez, \& Rascon, 2007; Casanave \& Hubbard, 1992; Cho \& Reich, 2008; Ferris \& Tagg, 1996; Roessingh, 2004; Watt, Rossingh \& Bossetti, 1996; Zamel, 1995). Research in second language education has also indicated that ESOL students have considerable challenges in 
their academic studies at North American schools and one of the challenges is their inadequate English proficiency (Braine, 2002; Cho \& Reich, 2008; Ferris \& Tagg, 1996; Huang, 2005; Huang \& Klinger, 2006; Huang \& Rinaldo, 2009; Kim, 2008; Watt et al., 1996).

The results of these studies showed that academic listening, speaking, reading, and writing skills have all been identified as challenging areas for ESOL students studying in North American schools. This was evidenced when Watt et al. (1996) found that ESOL high school students drop out at a rate of two to two and a half times that of their native English-speaking peers. Therefore, it is important to examine teachers' perceptions of their ESOL students' challenges in academic English skills in the K-12 classrooms and what has been found to be the most successful strategies imparted to their students. Few studies have investigated ESOL students in K-12 classrooms and fewer yet have conducted their investigation from more than one specific cultural or ethnic perspective, hence researching these areas can produce significant educational implications.

\section{LITERATURE REVIEW}

This section reviews the various findings on ESOL students' coping strategies specific to areas of academic listening, speaking, reading, and writing.

\section{Coping Strategies for Academic Listening}

In the past, it was believed that having ESOL students listen to lectures would be sufficient (Benson, 1989); however, today's ESOL listening programs emphasize comprehension. Research has shown that ESOL students are struggling in the classroom because they have difficulty comprehending what the teacher is saying (Huang, 2004, 2005; Huang \& Klinger, 2006). Therefore, it is important for the teacher to help them develop effective academic listening strategies. Cho \& Reich (2008) found that teachers of ESOL students need to increase comprehensibility by adjusting the way they speak. They found that many native English speakers tend to stress one or two syllables in a sentence and slur the rest which makes comprehension difficult for ESOL students because many of the sounds are unclear. Cho and Reich (2008) also suggested that teachers introduce new vocabulary daily to ESOL students to help build academic knowledge. This can be done by including visual aids and connecting learning to prior knowledge. Benson (1989) looked at this further and found that, in a university setting, students need to be able to listen to a lecture and pick out the important information for their notes. This proves difficult for the ESOL students because they have difficulty identifying the important information. As a remedy, Benson (1989) stressed the following four main principles on which a listening course 
should be based on: the need for learning to take place; the need for content to be related to past and anticipated experiences; the need for skills to be practiced; and the need to encourage participation.

Hinkel (2006) argued that today's methods of teaching listening skills are faulty. He believes that teaching comprehension skills based on the ESOL students' experiences, fails to activate higher order thinking; however, it does work better than the previous method (practice) which neglected comprehension. These two methods tend to forget about the pace of a teacher's or peers' speech, their grammar, cultural references, or colloquial expressions (Hinkel, 2006). Hinkel (2006) suggested a variety of listening instruction is necessary for students to succeed. Some stages recommended by Hinkel (2006) include: prelistening (provide information that students may not already know, in order to provide them personal experience), making predictions, listening for the main idea, listening intensively, and reflecting on what they have heard. If the students can do this, they will be more successful at developing their listening skills.

\section{Coping Strategies for Academic Speaking}

Speaking and listening strategies are closely related. As mentioned, Cho and Reich (2008) concluded that ESOL students have difficulty with the English language because teachers and peers are not speaking the language clearly. They tend to slur words in a sentence and this creates confusion for the ESOL students and therefore makes it difficult for them to copy in their own speech. Ferris and Tagg (1996) mentioned six areas within students' everyday lives where speech is vital. The areas include: class participation, working with peers, oral presentations, interacting with native speaking peers, and interacting with professors. Studies have found that students benefit most when they can interact fully with their teachers or advisors (Hansen, 2000; Braine, 2002; Roessingh, 2004).

Class participation is important because it will help ESOL students to build the confidence it takes to express their opinion and discuss it with the class (Ferris \& Tagg, 1996). Farr (2003) argued that students need to participate in class because it allows them to reflect on what they have learned. It also allows them to confirm to themselves and the teacher that they have fully understood the particular topic they are discussing. Ferris and Tagg (1996) suggested the best way to increase class participation for ESOL students is by giving them opportunities to voice their opinion, even if it is just asking if they agree or disagree. This will build confidence for further participation in the future. They also suggest having large-group and small-group discussions to give ESOL students a sampling of each setting. 
The second important area of speaking in ESOL students' lives mentioned by Farris and Tagg (1996) is working with peers. This is very similar to interacting with native speaking peers, and will be combined. They claim this is important because it helps build the ESOL students' ability to cooperate with their peers, both inside and outside the classroom. The more comfortable the ESOL students are with their peers, the better they will feel in and out of the academic classroom (Cho \& Reich, 2008).

A challenge for ESOL students is having simple conversations because they may not understand the components of a conversation. Farr (2003) identified three levels of a conversation. The first is pragmatics, (making the speaker aware that the students are listening); the second is the turn-taking system (understanding when it is the student's turn to speak); and the third is comprehension (showing the speaker the students understand what they are saying). Difficulty with these levels leads to a lack of confidence speaking to others (Farr, 2003; Ferris \& Tagg, 1996; Flowerdew, 1995). Flowerdew (1995) added to this by saying that individuals need to have proper background knowledge in order to have a successful conversation. This is especially true when taking part in a class discussion. If the students do not understand what is being discussed, then they will not participate. Ferris and Tagg (1996) suggested that the teachers assign projects that allow the students to work together, starting with in-class assignments and then moving into work that allows students to work with peers outside the class.

Ferris and Tagg (1996) cited oral presentation as the next important area for ESOL students. Presentations are not as common in elementary school but grow in importance as students enter high school. If ESOL students are not comfortable speaking the language, they will be less confident speaking in front of the class. Ferris and Tagg (1996) suggested having the ESOL students practice in a variety of different settings before having them present to the class. This will perpetuate a sense of confidence with the topic, and with the language itself.

The final stage of oral communication for ESOL students to develop is the ability to interact with instructors or advisors. Studies have found that ESOL students' success in the classroom increases greatly if the instructor or teacher is willing to put in the time (Braine, 2002; Ferris \& Tagg, 1996; Hansen, 2000; Roessingh, 2004). Hansen (2000) has suggested that constant communication with the instructor ensures that students are learning the necessary skills to benefit them in the classroom. Students should feel comfortable asking for help and instructors should be available to provide assistance when needed.

Hinkel (2006) proclaimed that pronunciation is another important area for ESOL students' to develop speaking skills. Recently, the focus of English 
speaking instruction has shifted from the ESOL students acquiring their host country's accent in place of their native accent. The current focus is on ensuring that ESOL students speak in a manner such that listeners can understand the intended meaning of what is being conveyed (Hinkel, 2006). Articulation, clarity, cadence, word-choice, and intonation are identified as the areas of focus for effective speaking.

\section{Coping Strategies for Academic Reading}

Similar to academic writing, academic reading has become an important issue as many schools fail to meet their adequate yearly progress goals, as stated in "No Child Left Behind", because their ESOL students are not confident in their reading (Slavin \& Cheung, 2005). Hinkel (2006) stated that students require prior knowledge of the conventions of print and the language of the text to build upon in order to succeed at reading. Without this prior knowledge, the ESOL students will be unable to process any of the information they are reading in English. Also, to read successfully, students must be able to visually determine what a word is and sounds like, then determine its meaning, and finally put it together with the sentence all within a few seconds (Hinkel, 2006). ESOL students struggle with this because they cannot process at the speed necessary to succeed. Recently, as a solution to this problem, a great deal of importance has been placed on vocabulary because students need to understand $98 \%$ of the words in a text to fully comprehend it (Hinkel, 2006). Hinkel (2006) also found that a vocabulary of 2000 words is critical for a social conversation, and 5,000 is the minimum for reading an academic text.

A possible solution suggested by Avalos et al. (2007) was modified, guided reading. This strategy involves having the students work in small groups and integrating reading, writing, listening, and speaking, while offering meaningful instruction. The modifications are designed to enhance and enrich language. This system, when used properly, can be very successful because it increases the opportunities for detailed vocabulary instruction and provides opportunities to examine text structure (main ideas, grammar, syntax, etc.) while including cultural relevance.

With respect to vocabulary instruction, Hinkel (2006) advised that teaching vocabulary must meet the following conditions: "interest, repetition, deliberate attention, and generative use [or using the word in context]" (p. 122). Teachers must be aware of this as vocabulary is a major component of reading. Hinkel (2006) also suggested extensive reading, (whether in class or individual). The more students read, the more they will learn. However, reading is based primarily on vocabulary. Students must not be afraid to ask for help when they 
do not understand a word, or else the meaning of the text may be lost. Students must also read material at a level with which they are comfortable, while providing a challenge to them as well (Hinkel, 2006).

\section{Coping Strategies for Academic Writing}

Writing is difficult for ESOL students because it is the combination of the other academic skills (reading, speaking, and listening). According to Zamel (1995), writing was the area of greatest concern for ESOL students. Hansen (2000) agreed, and claimed that teachers are the major problem as they tend to evaluate linguistic and rhetorical forms rather than the ESOL students' content. He also identified grammar as another major issue within the area of academic writing (Hansen, 2000).

Leki \& Carson (1997) looked at writing in terms of the type of assignments about which the ESOL students were asked to write. They came up with three potential writing topics: 1) assignments about the writers' personal experiences (i.e. my summer vacation), 2) assignments about a text to which the writers are supposed to respond, for which they provide an opinion, (Was the character happy or mad at the end of the story?), and 3) an assignment that asks the writers to show understanding (i.e. Reflect on the story read. How does the character grow?). Leki and Carson (1997) interviewed 27 university ESOL students about these topics. When asked about the hardest part with regard to writing, the majority of students said that it was writing without having a text to follow. The students also agreed that writing from the top of their heads presented a major limitation because they had a difficult time thinking of a topic and conveying their ideas clearly in written form. Another concern was lack of time, which, in turn, produced dissatisfaction with their work because they were rushed. Leki and Carson (1997) further stated that organizing ideas and finding the proper information from the text were difficult aspect of writing. Their suggestion was for students to use a graphic organizer to help provide structure to their writing.

Hansen (2000) took this further by discussing the writers' audience. He believes that it is easier for ESOL students to write for a specific audience rather than a large audience. It allows them to narrow their focus to a specific topic rather than writing broadly about something they do not fully understand. Hansen (2000) went on to argue that many ESOL writing courses tend to ignore what the students are learning in their content classes. This leads to more frustration for students. Hansen (2000) recommended, whenever possible, having the students write about topics they understand and in which they have a personal interest. If 
this is not possible or if the students lack sufficient understanding in order to succeed, the instructor should assist, mentor and instruct them as needed.

Another study suggested that writing instruction needs to differ among age groups. Hinkel (2006) argued that to properly teach writing to elementary school ESOL children, the instruction must go hand in hand with reading. This will help the students understand grammar and vocabulary along with proper sentence structure and organization. Hinkel (2006) also suggested having students start with emotive writing (personal experiences) to help build confidence and understanding of basic structure. In high school, the teacher must promote critical thinking by providing a variety of interesting reading materials and having the students analyze them (Hinkel, 2006). Critical thinking is vital to high school and further education, so it is imperative that teachers start as soon as possible to promote success for ESOL students.

Various studies have debated the best ways to teach writing to ESOL students. Kim (2008) recommended that students write journals as it will encourage them and promote organization, grammar and vocabulary. A recent idea that has proven useful for ESOL students is the portfolio (Zamel, 1995). It allows the students and teacher to observe the progress and to diagnose problems/difficulties from the past and ameliorate them. Zamel (1995) also suggested giving the students multiple opportunities to write in order to help them learn the language. Coursework that draws on personal experience, values, and other prior knowledge provide potential topics for expression.

\section{METHODOLOGY}

The purpose of this study was to discover what language skills are perceived by five ESOL classroom teachers to be problematic to their ESOL students' academic success at K-12 schools in western New York and southern Ontario, and what suggestions these teachers can make for ESOL students to improve their academic English skills at these schools. Specifically, this study attempted to answer the following three research questions: a) What are the important language skills for ESOL students to meet the expectations or standards of the classroom? b) What are the challenges/difficulties in acquiring academic language skills experienced by ESOL students in the classroom? and c) What are the strategies that ESOL students need to develop to cope with their challenges?

This study is qualitative in nature, involving five classroom teachers' perceptions about teaching ESOL students. Semi-structured interviews were conducted among the researchers and the participants. A random purposive sampling strategy was used to select participants because it added credibility to the study (Gay \& Airasian, 2003). A sample of five K-12 ESOL classroom 
teachers, three from Western New York (participants $A, B$, and $E$ ) and two from Southern Ontario (participants $C$ and $D$ ), participated in this study.

At the time of the interview, participants $A$ and $B$ were ESOL teachers at K-12 schools in western New York. They obtained their Bachelor of Arts degrees in TESOL from a private Catholic university in Western New York. Participant $A$ has experience in both elementary and high school classrooms. Participant $B$ has experience with Kindergarten through $8^{\text {th }}$ grade. She was working in Buffalo where she was the sole ESOL teacher in a school of 35 ESOL students. Participant $C$ worked in southern Ontario as an ESOL teacher for four catholic elementary schools. She obtained her Bachelor of Arts in TESOL from a university in southern Ontario and has been working as an ESOL teacher for four years. Participant $D$ obtained her Honors Bachelor of Arts, Bachelor of Education, and Ontario Teacher Certification with additional qualifications in ESL and Music. In addition, she has successfully completed six TESOL courses from a university in southern Ontario. Her teaching experience is extensive and varied, having taught since 1982. She has taught ESOL in elementary, high school and adult learning settings. She has also taught ESOL visiting summer students from Mexico and preschool to adult ESOL students in Greece. Participant $E$ held Bachelor of Arts and Master of Arts degrees, as well as a Master of Education in TESOL degree from a university in western New York. $\mathrm{He}$ had experience of 34 years of ESOL instruction at the middle, high school and college levels.

Face-to-face semi-structured interviews were conducted among the researchers and the participants. The participants were allowed to describe the reality of their experiences and opinions in the academic classrooms. Interview questions were developed based on the research questions that were described above. These interviews allowed for the identification of the teachers' perceptions of their ESOL students' problematic areas and suggestions they have for ESOL students to improve their academic English skills. A coding and classifying approach (Gay \&Airasian, 2003) was used for data analysis. Participants' responses relevant to research questions were grouped together and subsequently categorized and analyzed according to the recurring themes.

\section{RESULTS AND DISCUSSION}

From the interviews there emerged seven distinct areas of interest: 1) ranking of importance of academic listening, speaking, reading, and writing skills; 2) challenges that ESOL students face in the classroom (which has been addressed in a separate paper); 3) strategies to help ESOL students in academic listening; 4) strategies to help ESOL students in academic speaking; 5) strategies to help 
ESOL students in academic reading; 6) strategies to help ESOL students in academic writing; and 7) strategies to assist ESOL students in overcoming challenges in academic English skills. This paper focuses on the implementation of coping strategies for K-12 ESOL students in academic English skills, as perceived by their classroom teachers.

\section{Ranking in Order of Importance of Academic Listening, Speaking, Reading, and Writing}

When asked to rank the importance of academic listening, speaking, reading, and writing, the participants' responses were varied. Participant $A$ believed that reading and listening are the most important skills because reading can apply to listening, which leads to speaking and eventually, writing. Participant $B$ thought that reading and writing were most important and stated, "It is sad but we are so focused on testing and unless students can navigate through those questions...they cannot show their true knowledge". Participant $C$ stated that each influenced the other, "If students learn to hear and comprehend English it will lead to speaking, reading, and eventually writing the language." Participant $D$ found that listening and speaking skills were most important for early elementary students as they are the "basic skills of the four skills and provide a foundation for the latter." She identified reading as the next most important skill in later grades, stating that through reading "students are provided with models of various forms of writing which they may draw from and apply to their own writing." Participant $E$ indicated that reading and writing were the most essential skills his students require to be successful. He cited vocabulary as integral to success as his students "often do not know academic vocabulary and language in their native language, so there is no transfer of skills".

All five teachers answered the question differently because in each particular classroom, their students' needs differed. Participant $A$ has worked with students from all over the world, including Russia, Holland, China, Germany, and Puerto Rico. She believes that reading is the most important skill because it related to all the other skills. She stated, "You read aloud so they can associate word text or listening, and eventually they can apply to speaking if they read aloud too. I believe that reading is the be all and end all of education. If they get the reading they can learn on their own, in books. If they read more, their brain(s) [are] soaking up more because they read and then they apply."

Participant $B$ worked with students from Puerto Rico who were fluent in basic communication proficiency, but struggled with the academic language. She was torn between which of the two, reading or writing, was the most important because, according to her, "reading is such an important part of all courses. It 
tells you all your information. I feel reading is very important and I also feel, especially in high school, unless you can write, [you will not succeed since] all your classes require papers that help show your knowledge." It was easier to teach Kindergarten because "the things I am teaching are also being reinforced in the class. All students are learning their letters and their sounds and how to read. I am just giving them a bit more of a push to get over that language barrier."

Participant $C$ has also worked with students from all over the world, including China, Haiti, Mexico, and Albania. She believes that listening is most important because, as she stated, "they all influence each other, and on a day-today basis, a student needs to listen more than any other skill." After listening, participant $C$ listed speaking, then reading and writing as most important because they all lead to the other.

Currently, participant $D$ 's students originate from Honduras, Columbia, Serbia, Turkey, Egypt, Madagascar, Pakistan, Albania, Cuba, Angola, El Salvador, Afghanistan, and China. Many of her students are recent immigrants to Canada, having only been in the country for anywhere between two weeks to ten years. One of her students has autism and two suffer from Post Traumatic Stress Syndrome as a result of being victims of torture in their homelands. Her students' English proficiency ranges from little or no English to high school level proficiency. It is for this reason that she identifies different needs for her individual students based on their prior knowledge of English. According to participant $\mathrm{D}$, listening and speaking skills provide that base for understanding and communication that is needed to develop reading and writing skills.

Participant $E$ currently teaches seventeen, grade nine to twelve ESL students, two of whom are identified as having special needs and learning disabilities and one who is low functioning and is in a self-contained classroom setting. His students originate from India, Pakistan, Yemen, Puerto Rico and Italy and have been in the United States anywhere from a week to eleven years. Their English proficiency ranges from illiterate to intermediate readers and writers. He has found that students need good academic English skills in order to be successful in a school. He states that reading is the most important skill. "Once a student gets beyond basic social skills in English, reading holds the key" to his/her success. He identifies listening as the second most important skill, as "it leads to later fluency." Speaking skills are the least important according to participant $E$ because "everyone learns to speak eventually."

\section{Strategies to Help ESOL Students in Academic Listening}

The participants were asked what they thought was the most important academic listening skill an ESOL student would need most to meet expectations of the 
class. Participant $B$ said that, "being able to listen and understand what the teacher says, to pick out the main ideas, the important details, and ... to understand the content, are the most important academic listening skills. It has to do with the process in their head with switching from one language to another language. It is a very difficult process to begin with and it is harder to process everything, let alone pick out what is and is not important." Participant $A$ felt that the most important skill is not picking out the information but understanding the task; participant $A$ stated that, "once they are able to determine what they need to do, they can start picking apart what information is in front of them or what terms they should be listening for." Participant $C$ agreed with participant $A$ that, "the most important listening skill is understanding what you have to do. Once they understand what they need to do they will be able to pick out the information." At the high school level participants $D$ and $E$ felt that emphasis should be placed on students' ability to understand lecture materials. Therefore, it is important for students to develop critical listening skills in order to extract and rephrase the key points of the lecture. Participant $D$ also stressed the important of teaching note taking skills in order to "decipher what is relevant and what isn't".

In order to succeed at these skills, the five participants were asked to recommend some strategies to help ESOL students learn these academic skills. All five participants agreed that exposure to the language is the best strategy for understanding academic listening. Participant $A$ stated, "If you are stuck on the little words like $a$, or, and; just skip it...Give them those basic rules and that gives them the foundation from which they can grow."

Participant $B$ worded it differently by stating, "I think the more exposure to a language, the better. The more they are exposed at a level they understand, the more it increases listening skills. I think that teaching students how to listen to lessons and pick our information academically is important as well ... I think that getting them to role play to practice conversation (or) activities where one student knows something but needs to talk to another student to obtain pertinent information is also important. Students need more exposure to the English language by using lots of activities that encourage interaction."

Participant $C$ also believes that exposure is important but addressed the associated challenges. She stated that "the best situation is to have students in an English-speaking environment all day, but this is not what always happens because parents of ESOL students rarely speak English so the only exposure the student is getting to English is in the school. I like to encourage the students to speak English and interact with English-speaking peers. Many students feel comfortable talking to peers who speak their language and they speak that language to get by, but this is not helping them learn English. I try and make my 
students feel more comfortable speaking English by having activities that encourage interaction as well as providing a safe environment where the students feel comfortable asking questions and saying what is on their mind." The students need to experience the language through exposure to learn it effectively and be comfortable using it. Participant $A$ mentioned that she liked to listen to radio shows from the 1940s because it encouraged the class to listen to "different tone," slang and academic language.

Participants $D$ and $E$ recommended that students consider what the speaker's purpose is and pay particular attention to his/her word choice, body language and tone. They also recommended generalizing the main ideas and use visualization to organize the main ideas into structures. In the case of L1 learners, both instructors felt it advantageous for L2 students to take notes for L1 so they could focus on the task of listening and deciphering the intended message without distraction. Participant $D$ found it key to make students aware of the three different types of listening: aesthetic, efferent and critical. This allows the student to understand the purpose for listening and can then implement corresponding strategies to enhance their ability to be effective aesthetic, efferent and/or critical listeners. A strategy that she found useful for her students was for them to make connections to their own life experiences and reflect on them in relation to what the speaker was saying. When they employed this strategy, often, it "greatly increased their comprehension and retention of the speaker's intended message." In addition, all the participants encouraged students to listen to a variety of different speakers ranging from conversational to formal and academic. Participant $E$ felt it is essential for students to have opportunities to practice as that is the "only way they will become proficient efferent and critical listeners."

\section{Strategies to Help ESOL Students in Academic Speaking}

"First and foremost, I think they need to learn how to ask a question because if they can't ask the question, they will not get what they need," said participant $A$ when asked for the most important academic speaking skill. Speaking is important to daily functioning in the classroom because it allows students to interact with their peers socially and academically, and ask questions when they do not understand. "I think having class discussions is [essential to academic growth and success]. If I make sure the students have opportunities to speak and hear others speak, they will feel more confident," mentioned participant $B$. She went on to add, "give the students an opportunity to answer questions they know the answer to (to make them feel comfortable), then move to higher- ended questions that involve critical thinking." Participant $C$ felt comfort is very 
important and thinks that the promotion of self-confidence and self-esteem is especially important for young students.

Participant $A$ stated, "I love open discussions with the students. Sometimes I do read aloud (and) let them talk. If they make a mistake I don't pick it out ... I repeat what they are saying in the proper way so they are not on the spot with it. I just let them talk; they learn from there. They listen to what I am saying or what someone else is saying who is fluent and they pick up on it. It happens naturally." She is adamant that immersion in an English speaking environment is best for ESOL students, but is concerned with the prevalence of slang in her students' dialogue. "They always said things like 'Immagoin to the bathroom' and I'd say 'excuse me what is Imma? I have no idea what that is.' I then told them that they were not allowed to say that in my class until they explained the meaning of their slang."

Participant $B$ believed that general discussion was best and did not feel slang was as big a problem as participant $A$. She believes that the "more discussion the better" and that student participation should be interactive and fun. She also encourages students to talk more frequently, so they can feel more comfortable speaking the language. Once this occurs, she can then move to pronunciation and grammar.

Participants $C, D$ and $E$, recommended creating an atmosphere that is safe, where students feel comfortable taking risks. When giving oral presentations, the general consensus was to allow students to read from a paper until they become comfortable at speaking to an audience. Participant $C$ feels that in this environment, "have the students talk and feel comfortable talking then break down the language. I like to have them try and describe a picture to me using their words, and there is no wrong answer. As time progresses, I expect more detail from them and it makes them feel more comfortable with the language."

According to participant $D$, speaking skills are essential to her students' academic success and is best achieved when imparted with strong oral presentation and questioning skills. She suggests providing students with a variety of opportunities to practice via dramatic speaking activities. At the elementary level, she has found that by encouraging students to incorporate puppets and props, reader's theatre, choral reading, show and tell, author's chair and singing, "students are engaged and less apprehensive to speak publicly". With middle and high school students, many of the elementary suggestions "can be modified to be age appropriate. For example, students could do a theatrical production in lieu of a puppet show, or create and present original 'raps'." She explains that her classroom is "a very non-threatening environment. Most of the 
students love to talk and have no problem attempting to participate in discussions/ conversations or active learning activities. When speaking, they do, however, make structural mistakes and make poor vocabulary choices."

Participant $E$ puts less emphasis on the importance of speaking skills. He does not feel that students should be "forced to speak in class, as it only discourages and centers the students out". According to him, speaking will occur naturally; however, situations can be created to provide opportunities for this to occur more readily. Small group work, class discussion, conversations with peers and peer conferences are ways to promote student public speaking.

\section{Strategies to Help ESOL Students in Academic Reading}

All participants were well versed in the various reading strategies, but did not get many opportunities to apply them in class. Although the teachers' experiences were limited, they still provided examples of strategies they used in the classroom that worked for their particular students. Participant $A$ said, "I wish I could have done more read aloud with the elementary students. I did it with the high school students and they liked it. They didn't feel like they had to read. One strategy I would never use...is round robin reading. I will never use it. But the one thing (I will continue to use) is read aloud because I feel that my students' listening skills will improve. They listen to the words that are being spoken and follow along with the text. They will listen at a higher level of understanding than they normally would. With round robin reading, students are not listening to a fluent speaker when they should be."

Participant $B$ spoke of a new program at her school called, Read 180, which is a comprehensive reading intervention program proven to meet the needs of struggling readers in transitional Grades 3-12. According to participant $B$, the program directly addresses individual needs through differentiated instruction, adaptive and instructional software, high-interest literature and non-fiction, and direct instruction in reading, writing, and vocabulary skills. Participant $B$ praised this program and stated, "The students do a quick 20-minute reading and the program gives me their reading level and suggests books. It is great to give students books at their reading level."

Participant $C$ agreed with participant $B$ and added that "a big problem I see is students reading books out of their level. I try to encourage my students to read books they can understand. It helps to improve comfort and confidence levels." Participant $B$ also thinks that using a dictionary "can be helpful but they shouldn't need to use it for 10 words a page. They should need to look up 1 or 2 words a page. This will be the sign to see if the book is too easy or too hard." Participant $D$ expressed concerns over her students using dictionaries as a 
reading strategy. Though she feels that vocabulary is key to reading success, she has found that some of her "students become dependent on the dictionary for translations and often make poor or inappropriate word choices as a result." She therefore advocates teaching students to use dictionaries and thesauruses properly. Assigning additional readings of varied genre is what she recommends to expand students' vocabulary. She prefers students to use context clues from the text to decipher word meaning and use the dictionary as a backup tool.

Participant $E$ recommends students read an easier level to ensure frustration does not occur. He agrees that guided reading questions and dictionaries help student comprehension, but also advises students read similar types of text. "The repeated exposure to a particular genre allows students to better understand specific writing styles, language and formats." By reading similar texts students will have an easier time locating the main idea of a text, and the supporting details which will improve reading comprehension.

Like participant $E$, participant $A$ asks her students to look for the main ideas of the text by providing them with a question on the board that requires the students to look for the answer in the assigned readings. This helps them with comprehension." Participants $B$ and C, however, were not aware of any successful strategies for comprehension while reading. Their primary concerns were reading levels and making sure the students were reading books they could understand.

\section{Strategies to Help ESOL Students in Academic Writing}

All of the participants spoke about the importance of graphic organizers for ESOL students. "I think graphic organizers are wonderful. If I give students an assignment, they often don't know where to start. When I give them an organizer, they have all the information and they feel comfortable with what they write ... they just need to understand the structure," said participant $B$. Participant $C$ mentioned that her initial focus is not on grammar but content and organization. She instructs her "... students to organize their ideas in the graphic organizer and once they are done they can begin writing their assignment."

Participant $B$ believes that along with the graphic organizers, the ESOL students should be encouraged to read more. She stated that "they just need to understand the structure. They will get this through reading." Participant $C$ agreed and said that, "the more students read, the more they will see how writing should 'look'. The students will understand structure and punctuation, and if they read a lot they will learn more vocabulary." Participants $B$ and $C$ both discussed the important of topic. Participant $C$ suggested that "students will write better on a topic if interested in [it]." She often begins the year with "topics about their 
lives; this makes them feel comfortable and confident" and it provides insight on her students' lifestyles, beliefs, values, cultures and interests. Participant $B$ concurred and stated that "the topic is important. If you focus on a topic that involves students' background knowledge, then the students should have little difficulty. It is important to relate the writing to the students' lives or interests." This allows the students to write from a position of authority and expertise.

Some specific writing strategies participant $D$ imparts her students are the proper use of a variety of graphic organizers through modeling, and then use them before writing the first draft. "Reading structured pattern examples and following the sample format to create original work" was what she reported to one of the most effective strategies for improving her students' writing.

Participant $E$ agrees with $D$ that there is a direct correlation between reading and writing. He too, sees the value of reading to understand written structure. Using graphic organizers to brainstorm and structure writing pieces is the first step to writing a well crafted, polished piece. Participant $E$ teaches his students to get in the practice of "continual revision by completing several drafts and conferencing with peers and the teacher."

\section{Strategies to Assist ESOL Students' Challenges in Academic English Skills}

Participants were asked what they thought their students needed to be academically successful. Participant $A$ indicated that students needed a better grasp of proper grammar in order to excel academically. She also indicated that she feels "if General Ed teachers had more of a background in ESOL, they could apply what they are teaching in a different form to help the students out." Participant $B$ stated a need for support from the ESOL teacher and the students' general education teacher. She commented that "with the support and proper teaching methods, students can definitely be successful in English and their content areas." Participant $C$ 's response was similar to $B$, but she added that "ESOL teachers and general education teachers must communicate and use similar teaching strategies." In many school systems ESOL teachers and general education teachers do not work together as they should. If they did, the process would be easier for the ESOL teacher and the students.

Participant $D$ noted that "students coming from different language backgrounds and cultures have different challenges and therefore different needs. For example, I have noticed that Asian students know the grammar, but have difficulty listening and speaking. Spanish speakers typically have more problems with the grammar, but not the listening and speaking as much. I have found it best to give all students a toolbox if you will, of strategies to draw from. This way they can see what strategies best fit their particular needs and learning 
styles." Several strategies her students find useful are: "keeping personal organizers of words and sentences; marking stress and noting pronunciation and grammar rules." Many of her students prefer to "brainstorm together for ideas, and use categorization and games for memory." As a final question, the participants were asked for their top 5 helpful strategies to develop language skills in K-12. Participant $A$ said, "The first is just to practice and not be afraid to make mistakes, everyone makes mistakes. I feel that sometimes our emphasis is on being perfect. That is not acceptable. You cannot have that expectation. The second strategy is not to hold unreasonably high expectations. If I teach a grammar rule once, they are not going to [understand] it; it is not realistic to expect that they will.You have to be patient with it. Another strategy would be to focus on what they need to learn; if you see a consistent error in their grammar, do a mini lesson on it. The fourth would be to ensure that they are comfortable. Be their friend in addition to being their teacher. [Sometimes] they will come in and just need to talk. I [tell my students] to come in and have fun, but when we need to do something we are doing it and that is it. The fifth strategy that I find helpful is for them to know they are accepted for who they are. If a student from India wants to wear a Sari to school, I will tell her she's beautiful. Let them be who they are. The first thing I say to my class is, 'Hi, this is me, what do you want to learn? What do you want me to do?' Students need to do things that interest them and that they feel comfortable doing."

Participant $B$ said, "I think the number one strategy is to engage students in interactive, fun projects. I don't think lecturing is going to help much. I think they need to use the language and get more experience speaking and being around it. I think projects and group work are important to use in class; it will help the students understand the content, while building confidence with peers. It will help them with comprehension; the more hands on experiences, group work, and class discussions in a class, the more comfortable the students will be with the language. Another important strategy is teaching students note-taking. The students need to be able to know what is important to listen for, and then write the main ideas and details. This is a [vital] strategy, we [as teachers] need to focus on. A fourth strategy is teaching reading comprehension. My students read, but do not understand what they are reading. I get them to slow down, and I teach them how to find the main idea, and what to do when they do not understand what they are reading. Finally, I feel that activating background knowledge is critical. It is important to relate to students' lives and make lessons relevant to them."

Participant $C$ said, "first and foremost, I think making the students feel comfortable in my class [is of primary import]. I want them to want to learn the 
language so I encourage them to do or bring whatever makes them feel comfortable. Personally, I like to start with the students going over information they already know to make them feel more comfortable; this may include reading a book they have already read or ask questions about information we covered last time. This lets me see where the students are and whether they are comfortable with that topic. My second strategy is working on reading comprehension. I like to read with the student to see how fluent their reading is. Afterwards I ask the students questions about the book to see how much of it they understood. I can determine the students' levels and whether or not they have improved. If it is clear they are struggling, then I need to help the students find strategies that work. If the students are struggling with vocabulary, they can use a dictionary; if they are struggling with finding the main ideas we will sit down and go over the reading. Another strategy I employ is the use of graphic organizers. This helps the students organize their ideas before they start writing. I have found that graphic organizers have helped tremendously to improve their quality of writing. They can be beneficial for all students, but specifically for ESOL students. The fourth strategy is modifying ESOL students' presentations. When ESOL students present, they should be allowed to read from their sheets or from the board instead of memorizing. Finally, I believe that it is important to encourage the students to use the language as much as possible. Practice makes perfect. Many students who are learning English go home to a household [where no English is spoken]. The best way to learn the language is to use it all the time."

When asked what he deemed to be the five most valuable strategies to attain success, participant $E$ cited, "memorization, particularly of spelling patterns; guessing meaning from context in reading and making two or more drafts of most writing." In contrast, participant $D$ identified "modeling, writing and reading workshops that incorporate active learning activities, peer mentors, cooperative learning and emotional coping strategies" as the most vital strategies to enable ESOL students to enable them to overcome the challenges before them.

\section{CONCLUSION}

In conclusion, this study investigated five North American K-12 classroom teachers' perceptions of ESOL students' challenges in academic English skills and strategies for improving ESOL students' academic English skills. In order to be academically successful, ESOL students need to develop effective strategies to improve their academic English listening, speaking, reading, and writing skills. The results are important for K-12 teachers, ESOL students, and their parents. The results also have implications for K-12 schools with ESOL students. It is hoped that the results of this study will not only help ESOL students but also 
their content teachers begin to understand the challenges that ESOL students can be expected to face in North American K-12 schools and the coping strategies that can be developed to ameliorate these challenges.

\section{References}

Avalos, M. A., Plasencia, A. P., Chavez, C., \& Rascón, J. (2007). Modified guided reading: Gateway to English as a second language and literacy learning. The Reading Teacher, 61(4), 318-329.

Benson, M. J. (1989). The academic listening task: A case study. TESOL Quarterly, 23, 421-445.

Braine, G. (2002). Academic literacy and nonnative speaker graduate students. Journal of English for Academic Purposes, 1, 59-68.

Canadian Bureau for International Education. (2002, April 15). International student numbers hit record high, but Canada offers dwindling support for African students. Retrieved October 28, 2002, from http://www.cbie.ca/news/index_e.cfm?folder=releases\&page

Cassanave, C. P., \& Hubbard, P. (1992). The writing assignments and writing problems of doctoral students: Faculty perceptions, pedagogical issues, and needed research. English for Specific Purposes, 11, 3349.

Cho, S., \& Reich, G. (2008). New immigrants, new challenges: High school social studies teachers and English language learner instruction. Heldref Publications, 235-242.

Farr, F. (2003). Engaged listenership in spoken academic discourse: The case of student-tutor meetings. Journal of English for Academic Purposes, 2(1), 67-85.

Ferris, D., \& Tagg, T. (1996). Academic listening/speaking tasks for ESL students: Problems, suggestions, and implications. TESOL Quarterly, 30(2), 297-320.

Flowerdew, J. (1995). Research or relevance to second language lecture comprehension: An overview. In J. Flowerdew (Ed.), Academic Listening: Research Perspectives (pp. 7-29). Cambridge: Cambridge University Press.

Gay, L. R., \& Airasian, P. (2003). Educational research: Competencies for analysis and applications. New Jersey: Prentice Hall.

Hansen, J. G. (2000). Interactional conflicts among audience, purpose and content knowledge in the acquisition of academic literacy in an EAP course. Written Communication, 17(1), 27-52.

Hinkel, E. (2006). Current perspectives on teaching the four skills. TESOL Quarterly, 40(1), 109-131.

Huang, J., \& Rinaldo, V. (2009). Factors affecting Chinese graduate students' cross-cultural learning at North American universities. International Journal of Applied Educational Studies, 4(1), 1-13.

Huang, J., \& Klinger, D. (2006). Chinese graduate students at North American universities: Learning challenges and coping strategies. The Canadian and International Education Journal, 35(2), 48-61.

Huang, J. (2005). Challenges of academic listening in English: Reports by Chinese students. College Student Journal, 39(3), 553-569.

Huang, J. (2004). Voices from Chinese students: Professors' use of English affects academic listening. College Student Journal, 38(2), 212-223.

Kim, Y. (2008). The effects of integrated language-based instruction in elementary ESL learning. The Modern Language Journal, 92(3), 421-451.

Leki, I., \& Carson, J. (1997). Completely different worlds: EAP and the writing experiences of ESL students in university courses. TESOL Quarterly, 31(1), 39-70.

Roessingh, H. (2004). Effective high school ESL programs: A synthesis and meta-analysis. The Canadian Modern Language Review, 60(5), 611-636.

Slavin, R. E., \& Cheung, A. (2005). A synthesis of research on language of reading instruction for English language learners. Review of Educational Research, 75(2), 247-285.

U.S. Department of Education. (2008). Retrieved June 26, 2008, from http://www.ed.org.

Watt, D., Roessingh, H., \& Bosetti, L. (1996). Success and failure: Stories of ESL students' educational and cultural adjustment to high school. Urban Education, 31(2), 199-221.

Zamel, V. (1995). Strangers in academia: The experiences of faculty and ESL students across the curriculum. College of Composition and Communication, 46(4), 506-521. 
Jinyan Huang is an associate professor and member of the graduate faculty in the College of Education at Niagara University. His research centers on the follow8ing areas: 1.ESOL students' learning challenges and coping strategies; 2. Factors that affect ESOL students' learning outcomes; 3. Reliability, validity, and fairness issues of ESOL assessments; and 4. The use of assessment data for supporting ESOL leadership and policies. He can be reached at jhuang@niagara.edu.

Alexis Smith is a recent graduate in Elementary and Special Education from Niagara University and is currently working with special needs students at Summit Academy in New York State. Previously she was Dr. Huang's research assistant and worked on projects dealing with K-12 ESOL students' learning issues. She can be reached at alexismsmith@ hotmail.com.

R. Michael Smith is an associate professor of Education in the College of Education at Niagara University. His research centers on the following areas: 1. Constructivism; 2. ESOL students' learning outcomes; and 3. Authentic assessments. Dr. Smith is also interested in study abroad programs. He can be reached at msmith@niagara.edu. 